\title{
In Response to a Call: Evoking a Keynote
}

Cultural Studies $\leftrightarrow$ Critical Methodologies

$1-3$

(C) 2016 SAGE Publications

Reprints and permissions:

sagepub.com/journalsPermissions.nav

DOI: 10.1 I77/I5327086/6673656

csc.sagepub.com

\author{
Alison L. Neilson' and Rita São Marcos'
}

(SAGE

\begin{abstract}
This is an escape from individualism, competition, and transmissive education practices which are the norms within higher education conferences of the neoliberal university. It is built from the script of a video abstract submitted to a call for keynote presenters for an international congress. Using tricksters and poetic presentations, we offer an open work inviting readers to have fun and make meaning from our provocative attempts.
\end{abstract}

\section{Keywords}

arts-based inquiry, decolonizing the academy, methods of inquiry, pedagogy, video, performance technologies

\section{Social Construction of Knowledge: Acknowledging the Trickster}

Since the rise of neoliberalism in the 1970s, the World Bank and International Monetary Fund in pressuring nations to pay back loans, have laid claim to education systems (Mundy, 2005) promoting individualism, competition, and economic growth, and instigating metrics of evaluation, precarious work, and managerial control of higher education (Verger, 2009) regardless of scholarly critique. The strength of neoliberalism in all levels of education lies in its invisibility as neutral while it colonizes knowledge to be simple, linear, and pre-determined. Because knowledge is embedded in a multitude of social and ecological systems, higher education needs to deal holistically with the coexistence of multiple levels of being, knowing, and doing. Yet, speeding to keep up with the volume of literature and conferences, scholars do not have time to pay attention to how we reinforce these neoliberal norms via the informal education that occurs as we mutually encourage these practices in ourselves, our colleagues, and students. Strong resistance exists including the call to slow scholarship (Mountz et al., 2015) and creative forms of research (Harris, Hunter, \& Hall, 2015; Onsès, 2015) which have inspired us in their ability to promote reflexive practice and disrupt hegemony (Nolan, 2014). But still, unchallenged pillars of neoliberalism dominate in the practices of conferences and publications, even in those critical of neoliberalism.

We are weary of keynote presentations that consist of an individual, regardless of how brilliant they may be, as a solo voice, at the center of the stage addressing the audience with a pre-defined one-way message. We have seen and used colourful, exuberant forms of multi-directional communication ranging from ancient storytelling to new technologies which better serve to include diverse peoples and complex contested realities. Therefore, we are trying to let pre-recorded neoliberal messages go unanswered to call back the missed calls from academics, activists, and artists who invite us into practices which are based on cooperation, collaboration, and serving justice. In sharing our experience here, we also move from our beginning paragraphs based mostly in transmitting our messages, to a more open, creative collective process of meaning-making, which we understand as an alternative to neoliberal practices. In this way, we continue to emphasize the collective rather than the individual, the process over the product, and privilege deliberative, democratic learning opportunities. Our reporting of our attempted escape germinates from indigenous storytelling with Coyote the trickster-deliberately messy and ambiguous, shifty with words, but full of extensive connections to diverse time and space, and life and death.

\section{The Call of the Trickster}

Once upon a time, a tree was a tree, but sometimes it was a rock. Research and education were easy when everyone followed the rules, but every once in a while, a rock decided that it was a tree, which made the already balding scientists pull out even more of their hair. Coyote liked this time, for a while, because in her vanity, she was always collecting hair for her "just in case wig" afraid to lose her beautiful fur coat. A time came when people had an idea that a tree was no longer a tree unless the gang of professional tree-namers said it was so. A tree could also be Alice or Manuel. Coyote

\footnotetext{
'University of Coimbra, Portugal

Corresponding Author:

Alison L. Neilson, Centre for Social Studies, University of Coimbra, Colègio S. Jerónimo, Apartado 3087, 3000-995 Coimbra, Portugal.

Email: aneilson@ces.uc.pt
} 
whined and whimpered and then with a flash of inspiration sent the gang a gift of ego, hubris, and a mouthful of long words. This created enough chaos that it became once upon a time again, the way she liked it. This is the story of once upon a time. It is a story of a tree, or maybe, of a rock and coyote's gifts. ${ }^{1}$

\section{An Attempted Escape}

To fill a missing keynote address, organizers of a "World" education congress called for short video abstracts to demonstrate expertise and ability. We, a collaboration of 11 people, ${ }^{2}$ tried to transform norms of knowledge construction via our submission. ${ }^{3}$ We used creativity as praxis of critical thought to oppose competition and privatization of knowledge normalized by neoliberal practices. Our multilingual Council of Animals, a wild risk-taking synergetic experiment, was not chosen for the keynote, but we present the script of the video as an attempted coup of individualism and apolitical practice to that of mutuality, interdependency, and introspection (Gahman, 2016). A deliberate use of ambiguity seeks to restore dignity and give up attempts at control. We invite an escape from neoliberalism's domestication of higher education and offer an Open Work (Eco, 1989), in that the reader and Coyote co-create with us, a moment of meaning-making, never static, new in every reading.

\section{In Response to a Call-Evoking a Keynote}

When WEEC asked, so you think you can dance?

A spontaneous council of animals was evoked, and this video was born. ${ }^{4}$

We need to get grants said the Meerkats ... time and space, there is a race and the Troika must be paid. ${ }^{5}$

\section{St. Anthony's Sermon to the Fishes ${ }^{6}$ Saint Anthony at church \\ Was left in the lurch, So he went to the ditches And preached to the fishes. \\ They wriggled their tails, In the sun glanced their scales. \\ The carps, with their spawn, Are all thither drawn; Have opened their jaws, Eager for each clause. \\ No sermon beside \\ Had the carps so edified.}

Education? Thought Coyote who wrote "Environmental" then "Sustainability" before laughing and scratching both out to write "Anthropocene."
The humans looked at one another confused, when a fiery red fox said, "only in circle, only in circle will we write."

No sermon beside Had the carps so edified.

There IS a common tragedy, but not of the type you think. ${ }^{7}$

"I" said ego, "me" said pride, "hmph" thought spirit, what a ride.

No sermon beside

Ptarmigan, caribou, Arctic char $^{8}$

No sermon

Seeds and songs, skype the mess,

Roam and wonder, corrupt and caress

Breath in, breath out. Theory and practice: one with the other, none without the other.

Relishing random ...

$$
\begin{aligned}
& \text { riffing relationships ... } \\
& \text { rhyming ridiculously ... }
\end{aligned}
$$

What!! groaned a great big bear, is this all about?

AGHHHH . . . said Alison, I can't do this alone

Gosh, said Rita, whatever gave you the idea that you were alone?

\section{Acknowledgments}

Keynote address was conceptualized with the following list of people as well:

Reingard Spannring, Department of Educational Science, University of Innsbruck, Austria

Leesee Papatsie, Feeding My Family, Iqaluit, Nunavut, Canada Miye Tom, Centre for Social Studies, University of Coimbra, Portugal

Eimear O'Neill, Transformative Learning Centre, Ontario Institute for Studies in Education, University of Toronto, Canada

Maria Paula Meneses, Centre for Social Studies, University of Coimbra, Portugal

Níels Einarsson, Stefansson Arctic Institute, Akureyri, Iceland

Diana Visintini, Punta Ballena, Puerto Pirámide, Chubut, Argentina

Judite Fernandes, Lisbon, Portugal

Garry Enns, International Peace Garden, Boissevain, Canada

\section{Declaration of Conflicting Interests}

The authors declared no potential conflicts of interest with respect to the research, authorship, and/or publication of this article.

\section{Funding}

The authors received no financial support for the research, authorship, and/or publication of this article. 


\section{Notes}

1. Coyote is a trickster who appears in many First Nations. As a White settler from Canada, Neilson (2007) hopes she speaks with Coyote in a respectful manner. She is inspired by Thomas King (2003).

2. We are activists, educators and researchers from Argentina, Austria, Canada, Iceland, Mozambique, Portugal, and the United States, individually and collaboratively with decades of experience. We have organized WEEC and other international conferences, given solo keynote addresses and have been recognized as academic and community leaders.

3. WEEC2015 Keynote proposal video and blog https:// weec2015.wordpress.com/ As a video, the images converse with the text as well.

4. from Joanna Macy's idea of "Council of All Beings" (Seed, Macy, Fleming, \& Naess, 1988).

5. The Troika is the International Monetary Fund, European Central Bank and European Commission which has provided emergency funds to Ireland, Greece and Portugal in exchange for compliance to structural readjustments and policies of austerity. Argentina has similarly suffered through International Monetary Fund (IMF) economic interventions as well, see The Role of the IMF in Argentina, 1991-2002, www.webcitation.org/63wJpvWcS. Einarsson (2011) discusses how fish, privatization, international financial practices caused bank collapses and social upheaval in Iceland.

6. Abraham a Sancta-Clara (1644-1709), a satirical critique of St. Anthony conversion of heretics, full poem www.public-domain-poetry.com/abraham-a-sancta-clara/ st-anthonys-sermon-to-the-fishes-39184

7. Phrase coined primarily by Hardin (1968) "Tragedy of the Commons": people always act selfishly to take as much of the commons for themselves and it is inevitable they will destroy it. This assumption is used to justify privatization of fisheries and other commons. Traditional fishers, indigenous peoples and others who have used the local commons end up being excluded by those who buy access to resources. Multiple people (Feeny, Berkes, McCay, \& Acheson, 1990) show that Hardin ignored examples of protection of the commons from over-exploitation without enclosure. Hardin also ignored the influence of colonial rule which destroyed local communities and customs of sustainability.

8. Ptarmigan, caribou, Arctic char are alive, these words dance in my mouth mimicking the way they fly, run and swim. The satisfaction my mouth gets from making these sounds links me to the experience of eating. This line is a direct link to Leesee Papatsie's account of going fishing, the costs involved and the work being done in Nunavut, Canada to reduce the cost of eating in the north www.facebook.com/ groups/239422122837039/.

\section{References}

Eco, U. (1989). The open work. Cambridge, MA: Harvard University Press.

Einarsson, N. (2011). Fisheries governance and social discourse in post-crisis Iceland. The yearbook of polar law, 3, 479-515.
Feeny, D., Berkes, F., McCay, B. J., \& Acheson, J. M. (1990). The tragedy of the commons: Twenty-two years later. Human Ecology, 18, 1-19.

Gahman, L. (2016). Zapatismo versus the neoliberal university. In S. Springer, M. Lopes de Souza, \& R. J. White (Eds.), The radicalization of pedagogy (pp. 73-199). London, England: Rowman \& Littlefield.

Hardin, G. (1968). The tragedy of the commons. Science, 162, 1243-1248.

Harris, A., Hunter, M. A., \& Hall, C. (2015). Critical approaches to arts-based research. The UNESCO Observatory MultiDisciplinary Journal in the Arts, 5(1), 1-20.

King, T. (2003). The truth about stories. Toronto, Ontario, Canada: House of Anansi Press.

Mountz, A., Bonds, A., Mansfield, B., Loyd, J., Hyndman, J., Walton-Roberts, M., . . . Curran, W. (2015). For slow scholarship: A feminist politics of resistance through collective action in the neoliberal university. An International E-Journal for Critical Geographies, 14, 1235-1259.

Mundy, K. (2005, March, 11). Discourses of development: The view from education. Presentation at Deconstructing Disciplinary Discourses of Development III-Centre for International Studies, Toronto, Ontario, Canada.

Neilson, A. L. (2007). Trickster teachers. Alternatives Journal, $33(5), 4-5,45$.

Nolan, K. (2014). The heART of educational inquiry: Deconstructing the boundaries between research, knowing and representation. In A. D. Reid, E. P. Hart, \& M. A. Peters (Eds.), A companion to research in education (pp. 517-531). Dordrecht, The Netherlands: Springer.

Onsès, J. (2015, January 28-30). Expanding art-based research beyond art. Presentation at the International Conference on Arts-Based research and Artistic Research, Porto, Portugal.

Seed, T., Macy, J., Fleming, P., \& Naess, A. (1988). Thinking like a mountain. Gabriola Island, British Columbia, Canada: New Society Publishers.

Verger, A. (2009). WTO/GATS and the global politics of higher education. New York, NY: Routledge.

\section{Author Biographies}

Alison L. Neilson conducts research on the way sustainability is understood and manifest in education and policy. She studies the processes of education to understand how people are encultured into structures and how the issues and structures themselves are constructed. Together with Rita São Marcos and other artists, activists, and researchers, she has been building a network for arts-informed/related research with local and international events to support arts as a way of knowing.

Rita São Marcos holds a degree in communication design from the Faculty of Fine Arts, University of Lisbon and a master's degree in sociology. Her work involves exploring risk perception and communication in governance and public participation. Together with Alison Neilson and other artists, activists, and researchers, she has been building a network for arts-informed/ related research with local and international events to support arts as a way of knowing. 